JAN ROKITA

Uniwersytet Kardynaea Stefana Wyszyńskiego w Warszawie /

Cardinal Stefan Wyszynski University in Warsaw

iD https://orcid.org/0000-0002-1904-683X

\title{
Inspiracje graficzne Heinricha Paula Groskurta podczas tworzenia medalu koronacyjnego Fryderyka Augusta (Augusta III Wettyna) w 1734 roku
}

\section{Abstract}

Graphic inspirations of Heinrich Paul Groskurt while creating the coronation medal of Frederick August (August III Wettin) in 1734

\begin{abstract}
$\mathrm{T}$ he author describes in detail two examples of medallic and graphic works of art related to the title medals. As he shows, the basic purpose of the propaganda message of the medal presented in the article was to justify the rights of Frederick August Wettin to the Polish throne as the winner of the election of October 5, 1733. The author notes that works of art, which should be qualified as models of inspiration for Heinrich Paul Groskurt, the author of the medal of 1734, are of French provenance. This proves that the owner of the medal accepted the fact that the medallist was inspired by models from the Seine. Thus, the question remains open as to what goals the new Polish ruler was guided by when he agreed to record his own act of royal sacrament in reference to similar ceremonies held in France. At the same time, when analysing the reverse of the medal the author pays attention to two inscriptions on the reverse: in the rim and in the section in the lower part, which are a commentary to the scene of the coronation of Frederick August Wettin. The author claims that such a clear reference in their content to the electoral victory of October 5, 1733 becomes completely understandable in the context of actual historical events and the electoral victory of Stanisław Leszczyński on September 12, 1733.
\end{abstract}

Keywords: medal, obverse, reverse, August III Wettin, coronation 
STRESZCZENIE

\begin{abstract}
A utor szczegółowo opisuje dwa przykłady dzieł sztuki medalierskiej i graficzA nej mających związek $z$ tytułowymi medalami. Jak wykazuje, podstawowym celem przekazu propagandowego przedstawionego w artykule medalu było uzasadnienie praw Fryderyka Augusta Wettyna do tronu polskiego jako zwycięzcy elekcji z 5 października 1733 r. Autor zauważa, że dzieła sztuki, które należy zakwalifikować jako wzorce inspiracji dla Heinricha Paula Groskurta, autora medalu z 1734 r., sa proweniencji francuskiej. Świadczy to niezbicie o tym, że dysponent akceptował fakt, iż medalier podczas pracy inspirował się wzorcami znad Sekwany. Pozostaje więc otwarte pytanie, jakimi celami kierował się nowy polski władca, godząc się na utrwalanie własnego aktu sakry królewskiej w nawiązaniu do podobnych uroczystości odbywających się we Francji. Jednocześnie analizujacc rewers medalu, autor zwraca uwage na dwie inskrypcje rewersu: w otoku i w odcinku w dolnej części, stanowiące komentarz do sceny koronacji Fryderyka Augusta Wettyna. Autor twierdzi, że tak wyraźne odwołanie się w ich treści do zwycięstwa elekcyjnego z 5 października 1733 r. staje się całkowicie zrozumiałe w kontekście rzeczywistych wydarzeń historycznych i zwycięstwa elekcyjnego Stanisława Leszczyńskiego 12 września 1733 r.
\end{abstract}

Słowa kluczowe: medal, awers, rewers, August III Wettyn, koronacja

$\mathrm{P}$ rzystępując do pracy nad niniejszym artykułem, byłem świadom trudności zadania, którego się podjąłem. Prześledzenie bowiem przez współczesnego historyka procesu powstawania konkretnego dzieła sztuki medalierskiej - począwszy od wyboru wzorca inspiracji w postaci najczęściej okolicznościowej grafiki, rysunku, obrazu czy wcześniejszego medalu, skończywszy zaś na przeniesieniu go $z$ pietyzmem na medalowy krążek - okazuje się niejednokrotnie zadaniem bardzo trudnym. W wypadku wzmiankowanego medalu koronacyjnego Augusta III Wettyna taki wzorzec jednak udało się odszukać.

Podczas kwerendy szczególnie pomocne okazywały się zarówno XVII- i XVIII-wieczne kompendia oraz zbiory emblematyczne, jak i katalogi aukcyjne monet i medali wystawionych na aukcjach najbardziej liczacych się antykwariatów i domów aukcyjnych w Europie oraz na innych kontynentach. Większość niezbędnych materiałów została zdygitalizowana i udosteppniona nieodpłatnie szerszemu gronu badawczemu. Przypomnieć trzeba w tym miejscu zwłaszcza dwa projekty on-line z zakresu emblematyki i numizmatyki: Emblematica Online, upowszechniajacy najcenniejsze zbiory biblioteczne wiodących europejskich ośrodków akademickich, oraz Acsearch, umożliwiajacy dostęp do danych archiwalnych 
prywatnych instytucji zajmujących się sprzedażą numizmatów. Studiując powyższe pozycje, niejednokrotnie utwierdzałem się w przekonaniu, że wyobrażenia na medalu będącym przedmiotem mojej analizy powinno się definiować jako wypadkową wcześniej funkcjonujacych w ikonografii wzorców dostosowywanych każdorazowo przez medaliera do wymogów dysponenta czy aktualnych potrzeb chwili.

Jak dotąd medale koronacyjne Augusta III Wettyna ${ }^{1}$ nie były przedmiotem żadnej pogłębionej analizy. Podstawowe informacje o nich zamieszczano w katalogach wydawanych przy okazji kolejnych okolicznościowych wystaw poświęconych epoce Augusta II Wettyna i Augusta III Wettyna. Wymienić w tym miejscu należy choćby katalog wystawy Pod jedna korona. Kultura $i$ sztuka $w$ czasach unii polsko-saskiej. Zamek Królewski w Warszawie- 26 czerwca- 12 października 1997 roku oraz katalog Zbiory Poznańskiego Towarzystwa Przyjaciół Nauk w Muzeum Narodowym w Poznaniu. Katalog wystawy ${ }^{3}$.

Mimo upływu lat wciąż wartość naukowa mają cztery prace: Jana Chrzciciela Albertrandiego ${ }^{4}$, Edwarda Raczyńskiego ${ }^{5}$, Edwarda Hutten-Czapskiego ${ }^{6}$ i Feliksa Bentkowskiego ${ }^{7}$. Ich autorzy zadali

${ }^{1}$ Do pozostałych medali bezsprzecznie zwiazanych z koronacją Augusta III Wettyna należy zaliczyć ten autorstwa nieokreślonego medaliera, najprawdopodobniej Georga Wilhelma Vestnera, datowany na 1734 r. (E. Raczyńs ki, Gabinet Medalów Polskich oraz tych które się dziejów Polski tycza poczawszy od wstapienia na tron Augusta II aż do zgonu syna jego Augusta III [1697-1763], t. III, Wrocław 1838, s. 197, poz. 372), medal autorstwa Petera Paula Wernera, datowany na rok 1734 (ibidem, s. 196, poz. 371) i żeton autorstwa nieokreślonego medaliera z 1734 r. (ibidem, s. 198, poz. 374).

${ }^{2}$ Pod jedna koroną. Kultura i sztuka $w$ czasach unii polsko-saskiej. Zamek Królewski w Warszawie- 26 czerwca - 12 października 1997 roku, red. M. Męclewska, B. Gratkowska-Ratyńska, Warszawa 1997.

3 Zbiory Poznańskiego Towarzystwa Przyjaciót Nauk w Muzeum Narodowym w Poznaniu. Katalog wystawy, red. Z. Białłowicz-Krygierowa, M. Warkoczewska, Poznań 1982.

${ }^{4}$ J.Ch. Albertrandy, Historya polska ostatnich trzech wieków medalami zaświadczona i objaśniona, rękopism około 200 w polskim języku skreślony, a częścia $i$ po francuzku napisany, znajdował sie $w$ bibliotece $b$. Warszawskiego Towarzystwa przyjaciót nauk, [b.m. i r.w.] (opis interesującego nas medalu na k. 267-269v, nr IV).

${ }_{5}$ E. Raczyński, op. cit. (opis interesującego nas medalu na s. 196, nr 370).

${ }^{6}$ E. Hutten-Czapski, Catalogue de la collection des médailles et monnaies polonaises du comte E. Hutten-Czapski, t. I-V, St. Petersbourg-Cracovie 18711916 - opis interesującego nas medalu w t. II, s. 38, nr 2751 (srebro); t. IV, s. 372, nr 9916 (złoto).

7 F. Bentkowski, Spis medalów polskich lub z dziejami krainy polskiej stycznych, w gabinecie Król. Alex. Uniwersytetu w Warszawie znajdujacych się, tudzież 
sobie trud odnalezienia i skatalogowania medali zwiąanych $z$ osoba Augusta III Wettyna oraz określenia ich autorstwa, dat i miejsc wybicia czy - jak w wypadku Edwarda Raczyńskiego - tłumaczenia na język polski treści inskrypcji oraz wstępnych interpretacji treści i obrazów zawartych na medalowym krązku. We wszystkich wskazanych publikacjach znalazła się także informacja na temat medalu koronacyjnego autorstwa Heinricha Paula Groskurta z 1734 r. W badaniach nad związkami między medalierskimi a graficznymi wizerunkami Augusta III Wettyna niezwykle pomocne okazały się także prace Ewy Łomnickiej-Żakowskiej: Graficzne portrety Augusta II i Augusta III Wettynów w zbiorach Muzeum Narodowego $w$ Warszawie ${ }^{8}$ i Grafika portretowa epoki saskiej $w$ Polsce $w$ relacji $z$ późnobarokowa grafika europejska ${ }^{9}$.

Celem artykułu, prócz szczegółowej analizy kompozycji artystycznej medalu stanowiącego część spuścizny pozostałej po Auguście III Wettynie, jest odnalezienie i opisanie dzieł sztuki, z którymi mógł mieć styczność medalier podejmujący się wykonania medalu na zlecenie króla lub jego najbliższego otoczenia.

Koronacja Fryderyka Augusta Wettyna na króla polskiego, poprzedzona pogrzebami Jana III Sobieskiego i Augusta II Wettyna (15 stycznia 1733 r.), odbyła się 17 stycznia 1734 r. w katedrze na Wawelu ${ }^{10}$. Aktu sakry królewskiej dokonał biskup krakowski

ze zbiorów i pism rozmaitych lub podań zebrany i porzadkiem lat ułożony, Warszawa 1830 (opis interesujacego nas medalu na s. 153, nr 541, złoto i srebro).

${ }^{8}$ E. Łomnicka-Żakow s ka, Graficzne portrety Augusta II i Augusta III Wettynów w zbiorach Muzeum Narodowego $w$ Warszawie, Warszawa 1997.

${ }^{9}$ Ead e m, Grafika portretowa epoki saskiej $w$ Polsce $w$ relacji z późnobarokowa grafika europejska, Warszawa 1997.

${ }^{10}$ J. Staszewski, August III Sas, Wrocław 1989, s. 77. Warto w tym miejscu odwołać się także do innych prac tego autora: ide m, August II, Warszawa 1985; id e m, Polacy $w$ osiemnastowiecznym Dreźnie, Wrocław 1987 oraz Europa i świat w epoce oświeconego absolutyzmu, red. idem, Warszawa 1991. Cenne sa także publikacje innych polskich historyków na temat czasów Augusta III Wettyna: Jerzego Dygdały, Konfederacja krakowska Teodora Lubomirskiego z początków bezkrólewia 1733 roku a polityka Austrii wobec Rzeczypospolitej, [w:] Trudne stulecia. Studia $z$ dziejów XVII i XVIII wieku ofiarowane Profesorowi Jerzemu Michalskiemu $w$ siedemdziesiata rocznice urodzin, red. Ł. Kadziela, W. Kriegseisen, Z. Zielińska, Warszawa 1994, s. 46-54; ide m, Urażone magnackie ambicje czy racja stanu? U źródeł opozycji wobec kandydatury Stanisława Leszczyńskiego $w$ bezkrólewiu 1733 roku, [w:] Spory o państwo w dobie nowożytnej. Między racja stanu a partykularyzmem, red. Z. Anusik, Łódź 2007, s. 187-199; ide m, Wizerunek barokowego sarmaty i oświeceniowego Europejczyka, czyli August III Wettyn $i$ Stanisław August Poniatowski, „Wieki Stare i Nowe” 2014, nr 6(11), s. 38-57, a także Tomasza Ciesielskiego, Armia koronna w czasach Augusta III, Warszawa 2009; id e m, 
Jan Aleksander Lipski. Jeszcze przed koronacją Fryderyk August Wettyn podjał zabiegi zmierzające do objęcia schedy po ojcu. Należy przypomnieć, że jeszcze za życia Fryderyka Augusta Wettyna, 13 września 1732 r. Rosja i Austria zawarły traktat Löwenwolda (nazwany tak od nazwiska rosyjskiego dyplomaty Karla Gustawa von Löwenwolda), którego sygnatariusze zobowiązywali się po spodziewanej rychłej śmierci króla polskiego nie popierać kandydatury do tronu polskiego zarówno Stanisława Leszczyńskiego, jak i przedstawiciela rodziny Wettynów, opowiadając się za kandydatura „Piasta” lub infanta portugalskiego Emanuela ${ }^{11}$. W dniu 13 grudnia 1732 r. do Rosji i Austrii dołaczyły Prusy. Na dalszy bieg wydarzeń wpływ miała niechęć, jaką wykazywali przedstawiciele Rosji i Austrii wobec popieranej przez Francję kandydatury Stanisława Leszczyńskiego. W połowie marca 1733 r. wspomniane dwory zadeklarowały Wettynowi poparcie podczas elekcji w zamian za ustępstwa polityczne. Niepowodzeniem natomiast zakończyły się pertraktacje między dyplomatami pruskimi a reprezentantami Fryderyka Augusta Wettyna. Fryderyk Wilhelm I żądał bowiem odłączenia od Rzeczypospolitej i przyłączenia do Prus Prus Królewskich i Kurlandii. W momencie, kiedy Wettyn otrzymał deklaracje poparcia ze strony cesarza Karola VI Habsburga i carycy Anny Iwanownej Romanowej, rozpoczą zakrojona na szeroka skalę akcję mająca zachęcić przedstawicieli szlachty do poparcia na polu elekcyjnym jego kandydatury. Zadanie to powierzono wysłanym do Warszawy oficjalnym posłom Wettyna. Cena za austriacka deklarację poparcia było uznanie przez Fryderyka Augusta, na przełomie lipca i sierpnia 1733 r., sankcji pragmatycznej wprowadzonej przez Karola VI Habsburga ${ }^{12}$. Przyszły król polski zamykał sobie tym samym droge do korony austriackiej. Natomiast na mocy układu $z$ Rosja, ratyfikowanego 1 września 1733 r., Fryderyk August Wettyn uznawał protekcję carycy Anny Iwanownej Romanowej nad Rzeczapospolita oraz jej tytuł cesarski. Wettyn jedocześnie wyraził zgodę na objęcie władzy nad Kurlandia przez faworyta carycy - Ernesta Jana Birona.

Sejm elekcyjny rozpoczał się 25 sierpnia $1733 \mathrm{r}$. W dniu 12 września 1733 r. szlachta jednogłośnie obrała na następcę Augusta II

Propagandowy wymiar uroczystości dworskich $w$ pierwszych latach panowania Augusta III, „Wieki Stare i Nowe” 2015, nr 8(13), s. 46-68.

11 J. Staszewski, August III Sas..., s. 80.

12 Ibidem, s. 82. 
Wettyna Stanisława Leszczyńskiego ${ }^{13}$. Mimo że wkrótce potem Leszczyński $\mathrm{w}$ kolegiacie św. Jana zaprzysiagł pacta conventa, to jego panowanie od początku było zagrożone. Jeszcze 11 sierpnia 1733 r. granice Rzeczypospolitej, zgodnie $z$ postanowieniami traktatu sasko-rosyjskiego, przekroczyły wojska rosyjskie. Początkowo Rosjanie nie podejmowali żadnych wrogich działań, jednakże po elekcji Stanisława Leszczyńskiego, 12 września 1733 r. podjęta została decyzja o marszu na Warszawę. Świadomy niebezpieczeństwa Leszczyński w nocy z 21 na 22 września 1733 r. opuścił stolicę, udając się do Gdańska. W dniu 5 października 1733 r. po przybyciu na Prage wojsk rosyjskich została zorganizowana pod wsią Kamień druga elekcja - zwycięska dla Fryderyka Augusta Wettyna ${ }^{14}$. Natomiast 10 października 1733 r. wkroczył do Warszawy korpus wojsk rosyjskich. Ostatecznie 14 listopada 1733 r. przekazano do publicznej wiadomości informację, że Fryderyk August Wettyn wyraził zgodę na objęcie władzy w Rzeczpospolitej i zdecydował się przyjać oficjalne imię August III.

Interesujacy nas medal $z$ okazji koronacji Augusta II Wettyna wykonał Heinrich Paul Groskurt ${ }^{15}$ działajacy w Dreźnie (sygnatura A. P. GROSKVRT w dolnej części awersu) w 1734 r. ${ }^{16}$ (il. 1). Na

13 Ibidem, s. 90.

14 Ibidem, s. 99.

15 Heinrich Peter Groskurt (ok. 1694-1734) - przez pewien czas mieszkał i pracował w Berlinie, ale ostatecznie osiadł w Dreźnie. Wykonywał zlecenia głównie dla możnowładców z Brunszwiku, Prus i Saksonii. Najwięcej medali zrealizował dla Fryderyka Augusta I Wettyna. Do jego najlepszych prac należy zaliczyć: medal z 1730 r, upamiętniajacy przegląd wojsk w Zeithain pod Mühlbergiem trwajacy od 31 V do 28 VI 1730 r., medal uświetniający konsekrację kościoła w Salzdahlum z 1701 r., medal z okazji wycofania się Szwedów z Saksonii z 1707 r., medal z okazji małżeństwa księcia elektora saskiego Fryderyka Augusta Wettyna $z$ arcyksiężną Marią Józefą Habsburg z 1719 r., medal w następstwie zawarcia małżeństwa księcia Fryderyka II Hohenzollerna z księżniczką Christianą Elżbietą Brunszwicka w dniu 12 VI 1733 r., medal portretowy księcia-elektora saskiego i króla polskiego Fryderyka Augusta I Wettyna oraz jego małżonki Christiany Eberhardiny Hohenzollern z okazji urodzin księcia elektora z 1696 r. czy w końcu medal informujący o sojuszu Rzeczpospolitej, Prus i Danii przeciwko Szwecji z 1709 r. Por. L. Forre r, Biographical dictionary of medallists-coin, gem, and seal-engravers, mint-masters, \&c., ancient and modern, vol. II, London 1904-1916, s. 317.

${ }^{16}$ E. Raczyńs ki, op. cit., s. 196, poz. 370; Medale Polskie i z Polska zwiazane $z$ okresu pierwszej Rzeczypospolitej. Katalog zbiorów - zamek królewski w Warszawie - muzeum. Fundacja zbiorów im. Ciechanowieckich, red. J. Zachert, G. Śnieżko, M. Zawadzki, Warszawa 2019, s. 51-52, poz. 277. Na rynku antykwarycznym na przestrzeni ostatnich lat (2008-2020) zostało wystawionych na sprzedaż łącznie 15 interesujacych nas medali autorstwa Heinricha Paula Groskurta z 1734 r. 
awersie medalu artysta sporządził podobiznę Augusta III Wettyna w prawym profilu. Monarcha odziany jest w koszulę z marszczonym kołnierzem, kirys z okragłym wycięciem wokół szyi udekorowany na przedzie motywem roślinnym wraz $z$ obojczykiem $z$ analogiczna dekoracja roślinna i naramiennikiem folgowym oraz płaszcz z okragła broszą na wysokości lewego ramienia. Napis w otoku: D[ei] G[ratia] AVGVSTVS III REZ POL[oniae] M[agnus] D[ux] LITH[uaniae] D[ux] SAX[oniae] EL[ector] (Z Bożej łaski August III Król Polski, Wielki Książę Litewski, Książę Elektor Saski) informuje o tytulaturze władcy.

Wszystkie one nie różnią się od siebie pod względem szczegółów kompozycji oraz treści inskrypcji, co pozwala przypuszczać, że nakład medali musiał przekraczać liczbę kilku sztuk. Opisywane egzemplarze zostały wykonane ze srebra. Por. Przedmiot wystawiony na aukcji antykwariatu „Fritz Rudolf Künker GmbH \& Co. KG”, 19 VI 2008 r. (aukcja nr 141, kat. nr 4525); Przedmiot wystawiony na aukcji antykwariatu „Fritz Rudolf Künker GmbH \& Co. KG”, 12 III 2009 r. (aukcja nr 152, kat. nr 5473); Przedmiot wystawiony na aukcji antykwariatu „Auktionen Meister \& Sonntag”, 18 XI 2011 r. (aukcja nr 10, kat. nr 294); Przedmiot wystawiony na aukcji antykwariatu „Fritz Rudolf Künker GmbH \& Co. KG”, 27 I 2011 r. (aukcja nr 180, kat. nr 621); Przedmiot wystawiony na aukcji antykwariatu „Fritz Rudolf Künker GmbH \& Co. KG”, 21 VI 2011 r. (aukcja nr 189, kat. nr 2226); Przedmiot wystawiony na aukcji antykwariatu "Gerhard Hirsch Nachfolger”, 2 V 2012 r. (aukcja nr 281, kat. nr 2192); Przedmiot wystawiony na aukcji antykwariatu „Gerhard Hirsch Nachfolger”, 8 II 2013 r. (aukcja nr 288, kat. nr 4487); Przedmiot wystawiony na aukcji antykwariatu „Auktionen Münzhandlung Sonntag”, 9 XII 2014 r. (aukcja nr 20, kat. nr 1420); Przedmiot wystawiony na aukcji antykwariatu „Fritz Rudolf Künker GmbH \& Co. KG”, 11 II 2015 r. (aukcja nr 33, kat. nr 2368); Przedmiot wystawiony na aukcji antykwariatu „Auktionen Münzhandlung Sonntag”, 8 VI 2015 r. (aukcja nr 21, kat. nr 1152); Przedmiot wystawiony na aukcji antykwariatu „Fritz Rudolf Künker GmbH. \& Co. KG”, 27 VI 2017 r. (aukcja nr 293, kat. nr 1226); Przedmiot wystawiony na aukcji antykwariatu „Fritz Rudolf Künker GmbH \& Co. KG”, 7 II 2018 r. (aukcja nr 303, kat. nr 2488); Przedmiot wystawiony na aukcji antykwariatu „Heidelberger Münzhandlung Herbert Grün e.K.”, 13 XI 2018 r. (aukcja nr 75, kat. nr 1114); Przedmiot wystawiony na aukcji antykwariatu „Solidus Numismatik”, 6 X 2019 r. (aukcja nr 47, kat. nr 71); Przedmiot wystawiony na aukcji antykwariatu „Auktionshaus H.D. Rauch GmbH”, 3 XII 2020 r. (aukcja nr 111, kat. nr 1445). O egzemplarzu złotym interesującego nas numizmatu informowali z kolei Feliks Bentkowski oraz Emeryk Hutten-Czapski, por. F. Bentkowski, op. cit., s. 153, nr 541; E. Hutten-Czapski, op. cit., t. IV, s. 372, nr 9916. Natomiast o egzemplarzu medalu wykonanym wyłącznie $z$ miedzi napisał J.F. Hauschild w pracy Beytrag zur neuern Münz und Medaillen Geschichte vom XVten Jahrhundert bis jetzo, nebst einem raisonnirenden Verzeichniß einer beträchtlichen Sammlung von Medaillen in allen Classen und von allem Metall, auch einiger 100 Stück seltner Thaler, mit Anmerkungen von Johann Friedrich Hauschild, Dresden 1805, s. 230, nr 1415. 

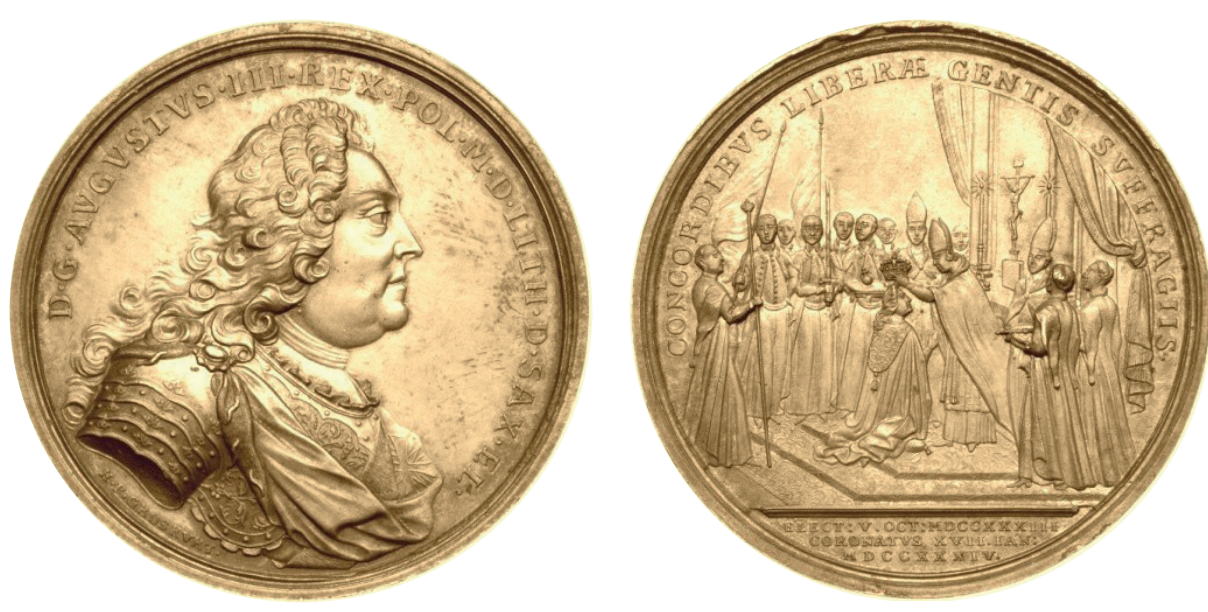

1. Medal koronacyjny Augusta III Wettyna, Heinrich Paul Groskurt, 1734, śr. 55,36 mm, rycina (Źródło: Gabinet medalów polskich oraz tych, które się dziejów Polski tycza począwszy od wstapienia na tron Augusta II aż do zgonu syna jego Augusta III [1697-1763], t. III, Wrocław 1838, poz. 370)

Rewers $z$ kolei inspirowany był rzeczywistym wydarzeniem, tzn. koronacja Fryderyka Augusta na następcę Augusta II Wettyna 17 stycznia 1734 r. Dwie najważniejsze postaci kompozycji, tzn. biskupa krakowskiego Jana Aleksandra Lipskiego oraz koronowanego księcia Fryderyka Augusta Wettyna, medalier ukazał w środkowej części krążka w następujących pozycjach: stojącej, w przypadku biskupa, i klęczacej, w przypadku księcia, na stopniach ołtarza nakrytych kobiercem $z$ motywem roślinnym. Biskup krakowski ma na sobie albę, rokietę, kapę biskupią oraz mitrę biskupią. Natomiast książę odziany jest w płaszcz koronacyjny podbity gronostajami. W obydwu rękach biskup dzierży koronę clausa, która unosi nad koronowanym księciem mającym obydwie ręce złożone w geście modlitewnym. Za plecami biskupa, na mensie ołtarza pod baldachimem, którego prawa połowa została przewiązana (w prawej części krążka), zlokalizowany jest krucyfiks między obydwoma płonącymi świecami w świecznikach. W prawej części kraż̇ka znajdują się trzy postacie. Ta najbliżej biskupa Lipskiego $\mathrm{w}$ albie, płaszczu biskupim, mitrze to zapewne biskup poznański Stanisław Józef Hozjusz lub sufragan poznański Adam Stanisław Grabowski. Dwie kolejne postacie w żupanach $z$ długimi rękawami i kontuszach $z$ rozciętymi rękawami oraz we fryzurach $\mathrm{w}$ postaci włosów przyciętych krótko i koliście, stojące tyłem i bokiem do oglądającego to reprezentanci szlachty. Pierwszego ze szlachciców 
z taca, na której leży berło w lewym, zgiętym w łokciu, ręku można identyfikować $z$ Janem Klemensem Branickim, ówczesnym chorążym wielkim koronnym i generałem artylerii koronnej. $Z$ kolei na lewo od postaci koronowanego księcia medalier utrwalił sześciu szlachciców w kontuszach zapinanych na guzy z rękawami rozciętymi na całej długości i żupanach $z$ guzami, przewiąanych pasami kontuszowymi oraz dwóch duchownych, w tym jednego biskupa pomocniczego w płaszczu spiętym pod szyją brosza i mitrze (biskupa poznańskiego Stanisława Józefa Hozjusza lub sufragana poznańskiego Adama Stanisława Grabowskiego). Dwaj szlachcice stojący najbliżej księcia to Ignacy Ancieta Zawisza - miecznik litewski - i książę Aleksander Jakub Lubomirski - miecznik wielki koronny. Pierwszy $z$ nich w obydwu rękach, zgiętych w łokciach, trzyma miecz koronacyjny zwrócony głownią do góry. Drugi natomiast w obydwu rękach, zgiętych w łokciach, prezentuje jabłko królewskie leżące na poduszce. Kolejny, nieznany z imienia i nazwiska szlachcic, zajmujący miejsce w pierwszym szeregu obok Ignacego Anciety Zawiszy, w lewym, zgiętym w łokciu, ręku ściska choragiew na drzewcu zakończonym grotem. Identyczna choragiew uwiecznił medalier w ręku jednego ze szlachciców w drugim rzędzie. $Z$ kolei postać $\mathrm{w}$ kontuszu $\mathrm{z}$ rozciętymi rękawami i żupanie $\mathrm{z}$ długimi rękawami wraz z laska marszałkowską w lewym, zgiętym w łokciu, ręku, zajmująca lewą część krążka, to marszałek wielki litewski (począwszy od 4 lutego 1734 r.) Paweł Sanguszko.

Warto w tym miejscu zacytować fragment opisu przebiegu koronacji $z$ artykułu Tomasza Ciesielskiego ${ }^{17}$. Autor korzystał $z$ zachowanych relacji opisu koronacji, w tym zwłaszcza z pracy Dyaryusz Prawdziwy wjazdu do stołecznego Krakowa... ${ }^{18}$ „Po wejściu do katedry August III klęknąl na położonym przed ołtarzem dywanie i zaprzysiąg1 pacta conventa [podkreślenie - J.G.R.], następnie został "iuxta Romanum rituale pomazany" i zaprowadzony do jednej $z$ bocznych kaplic, gdzie ubrał strój królewski. Przystrojony w dalmatykę oraz kapę powrócil pod ołtarz i padl przed nim krzyżem, kler odmówil Litanię do Wszystkich Świętych, a następnie August został koronowany oraz otrzymał insygnia władzy [podkreślenie - J.G.R.]. Jednym $z$ nich był miecz (ale nie

17 T. Ciesielski, Propagandowy wymiar..., s. 46-68.

18 Dyaryusz Prawdziwy wjazdu do stołecznego Krakowa $i$ koronacyi tamże, Fryderyka Augusta Elektora Sasuego [...], [w:] Dwie Koronacye Sasów Augusta II i Augusta III ze wspótczesnego rękopisu ogłosił [...] W. Syrokomla, przeł. W. Syrokomla, Wilno 1854, s. 21-28. 
Szczerbiec, a specjalnie sporządzony na tę uroczystość z długa, niemiecka klinga obosieczną), którym August III tak nieudolnie trzykrotnie zamachał w powietrzu, że "niektóre osoby śmiać się między soba poczęły, a inni mówić: spokojnego będziemy mieć Pana"”. Następnie biskup krakowski zaprowadził Wettina na tron, ogłosił go królem „wolnie” i zgodnie $z$ prawem wybranym, a następnie „zaśpiewał Te Deum laudamus i po trzykroć krzykną Wiwat Rex”. Przyjmujac przytoczony opis za wiarygodny, należy stwierdzić, że medalier mógł nawiązać na drugiej stronie swej pracy do momentu właściwej koronacji, kiedy monarcha „przystrojony w dalmatykę oraz kapę powrócil pod ołtarz i padl przed nim krzyżem. kler odmówil Litanię do Wszystkich Świętych, a następnie August zostal koronowany oraz otrzymal insygnia wladzy" [podkreślenie - J.G.R.] ${ }^{19}$. Kluczowego momentu leżenia przez monarchę krzyżem przed ołtarzem artysta jednak na swej kompozycji nie utrwalił. Natomiast, jak należy przypuszczać, epizod uwzględniony na drugiej stronie medalu nastapił niezwłocznie po wstaniu króla z pozycji leżącej.

Napisy w otoku: CONCORDIBUS LIBERAE GENTIS SUFFRGIIS (Zgodnymi wolnego narodu głosami) oraz w odcinku w dolnej części: ELECT[us] V OCT[obris] MDCCXXXIII CORONATIS XVI JAN[uarii] MDCCXXXIV (Obrany 5 października 1733. Koronowany 16 stycznia 1734) stanowia komentarz do kompozycji artystycznej i zawierają dokładną datę uroczystości koronacyjnych.

Bez watpienia twórca medalu podczas projektowania rewersu częściowo opierał się na rycinie Du sacre des rois de France, rytowanej przez Felixa Lacointa Mercure'a w 1722 r. ${ }^{20}$ (il. 2). Na pierwszym planie, w środkowej części, artysta ten uchwycił moment sakry królewskiej $z$ udziałem arcybiskupa de Rohan Guéméné (oznaczonego litera B) oraz następcy tronu Ludwika XV Burbona (oznaczonego litera A), przedstawionych kolejno w pozycjach: stojącej i klęczącej. Arcybiskup de Rohan Guéméné przywdział albę, rokietę, płaszcz (kapę) zapięty pod szyją i udekorowany wyobrażeniami lilii królewskich (na części zewnętrznej) oraz nieokreślonymi scenami, być może zaczerpniętymi ze Starego i Nowego Testamentu (na pionowych pasach, na obrzeżeniu części zewnętrznej), a także mitrę $\mathrm{z}$ paskami infulae. Natomiast następca tronu Ludwik XV

${ }^{19}$ Cyt. za: T. Ciesiels ki, Propagandowy wymiar..., s. 51.

${ }^{20}$ Bibliothèque nationale de France, Paris, sygn. G158956; Medale Polskie..., s. 51-52, poz. 277. 


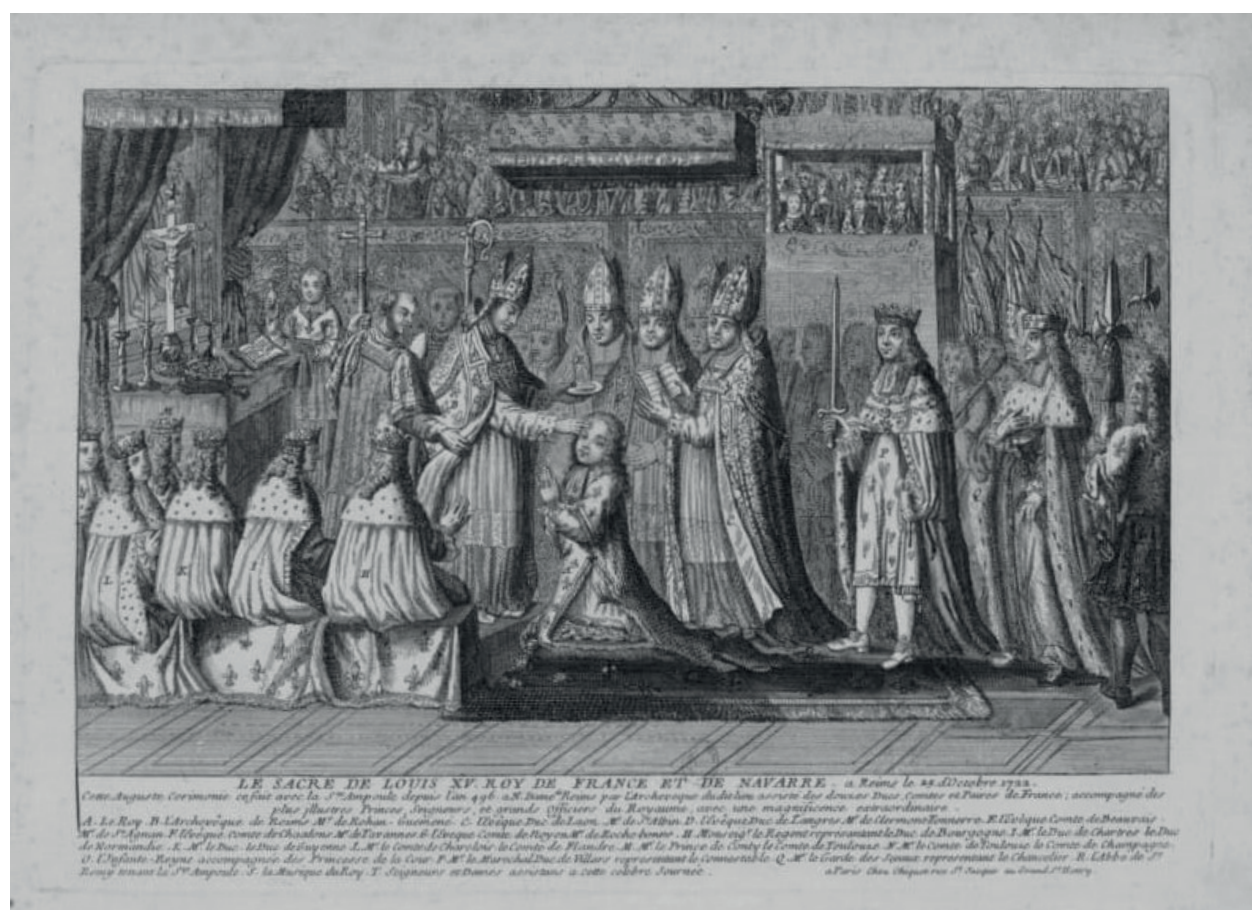

2. Rycina przedstawiajaca koronację Ludwika XV Burbona pt. Du sacre des rois de France, Felix Lacoint Mercure, 1722, miedzioryt (Źródło: Paris, Bibliothèque nationale de France, sygn. G158956)

Burbon odziany jest w szatę spodnią z długimi rękawami, szatę wierzchnia $z$ krótkimi rękawami, rozcięta po bokach i udekorowana broszą spinajaca dwie jej poły wraz z wyszytymi motywami lilii królewski (na części zewnętrznej) oraz żabot pod szyją. Arcybiskup, posługując się swą lewa, wyprostowana w łokciu, ręką i dwoma wysuniętymi palcami dłoni namaszcza skronie przyszłego władcy świętymi olejami. W prawym, również wyprostowanym w łokciu, ręku biskup dzierży okragła tacę. Obydwie, zgięte w łokciach, ręce Ludwika XIV Burbona pozostaja połaczone ze sobą w geście modlitewnym. Za plecami przyszłego monarchy rytownik wykonał podobizny pięciu kolejnych biskupów (oznaczonych literami: C, D, E, F, G). Trzech $z$ nich w pierwszym rzędzie (oznaczonych literami: C, D, E) ubranych jest podobnie jak arcybiskup de Rohan Guéméné. Analizując ich stroje, możemy wyodrębnić alby, rokiety, płaszcze biskupie i mitry $z$ paskami infulae (na głowach). Pierwszy $z$ biskupów tuż za plecami przyszłego króla, w płaszczu kapie $z$ wyszytymi motywami roślinnymi (po zewnętrznej stronie) oraz 
z naszyjnikiem $z$ krzyżem $\mathrm{w}$ obydwu rękach unosi otwartą księge do liturgii (oznaczony literą C). Dwóch ostatnich biskupów (oznaczonych literami: F, G) można rozpoznać jedynie po mitrach na głowach. Postać w szacie spodniej $z$ długimi rękawami (albie?) oraz szacie wierzchniej $z$ kwadratowym wycięciem wokół szyi i krótkimi rękawami zakończonymi frędzlami stojąca bezpośrednio za arcybiskupem de Rohan Guéméné to zapewne pomocnik głównego celebransa. W prawym, zgiętym w łokciu, ręku wymieniona postać ściska krzyż procesyjny, natomiast posługując się swą lewą, zgięta w łokciu, ręka, odsłania połę płaszcza arcybiskupiego. W dalszej części ryciny, przy ołtarzu posługuje kolejny kapłan w albie, rokiecie i mucecie (?), odpowiedzialny za pojemnik na święte oleje, uwieczniony w jego prawym, zgiętym w łokciu, ręku (w lewej części ryciny) (oznaczony litera $\mathrm{R}$ ). Za plecami biskupa $z$ księga liturgiczna (oznaczonego litera $\mathrm{C}$ ) należne miejsce zajmuje marszałek królewski książę de Villars w szacie spodniej (albie królewskiej?), płaszczu podbitym gronostajem, żabocie pod szyja, rękawiczkach oraz pończochach i trzewikach, a także $z$ łańcuchem $z$ Orderem Świętego Ducha, narzuconym na ramiona (oznaczony litera P). Głowę postaci honoruje korona clausa. W lewym zaś zgiętym w łokciu ręku portretowany ma miecz odwrócony głownią do góry. Następna postać (oznaczoną literą E) za plecami marszałka również przedstawił rytownik w długiej szacie spodniej (albie?) i płaszczu podbitym gronostajem. Natomiast głowę postaci okrywa futrzana czapka. Postać na skraju prawej części ryciny, w szacie $z$ długimi podwiniętymi rękawami i spódniczce, urozmaiconymi motywami lilii królewskimi oraz z partyzaną (w lewym, zgiętym w łokciu, ręku) to zapewne gwardzista królewski przypatrujący się aktowi sakry królewskiej. Sześć kolejnych postaci w płaszczach gronostajowych i koronach aperta (na głowach), siedzacych na ławie nakrytej materia $z$ frędzlami na obrzeżeniach i liliami królewskimi (po zewnętrznej stronie), odwróconych tyłem do oglądającego rycinę i przypatrujących się koronacji należy identyfikować z książętami Burgundii, Gujenny, Charolais, Flandrii i Szampanii (oznaczonymi literami: $\mathrm{H}, \mathrm{I}, \mathrm{K}, \mathrm{L}, \mathrm{N}, \mathrm{M}$ ). Na uwage zasługuję również wyposażenie i wystrój samego ołtarza $z$ wyobrażeniem krzyża maltańskiego na płycinie i leżącymi na mensie: krucyfiksem między parami płonących świec w świecznikach, księgą liturgiczna, korona clausa i berłem na poduszce (w lewej części ryciny). Nad ołtarzem 
zawieszony jest baldachim, którego dwie poły zostały zawiązane w celu lepszej prezentacji miejsca kultu.

$\mathrm{Na}$ drugim planie pojawiają się trzy postacie w krótkich płaszczach $z$ długimi bufiastymi rękawami i żabotami pod szyja (między biskupem $z$ księga do liturgii a księciem de Villars), a także postać w płaszczu $z$ długimi podwiniętymi rękawami i z płonąca pochodnią (za plecami księcia de Villars), oraz druga postać - zapewne duchownego pomagającego podczas sakry królewskiej w bliżej nieokreślonym ubiorze (między głównym celebransem a postacia z krzyżem procesyjnym). W górnej części ryciny artysta zrekonstruował widownię na wysokich drewnianych podestach obitych kobiercami z motywami roślinnymi, przeznaczona dla pozostałych uczestników koronacji (oznaczonych literą T), wśród których można wyodrębnić $m$.in. kobietę $z$ długimi włosami i rozwartymi rękami, na prawo od baldachimu ołtarza kościelnego (w lewej części ryciny). Dodatkowa loża $z$ dachem opartym na czterech kolumnach przeznaczona została dla widzów szczególnej rangi (oznaczonych litera O) (powyżej księcia de Villars). Wewnątrz loży w pierwszym rzędzie medalier sporządził podobizny czterech dam w pozycjach stojących $\mathrm{i}$ w sukniach $z$ obszernymi dekoltami. Na prawo od loży $z$ baldachimem, na dole, ustawione są cztery choragwie na drzewcach zakończonych grotami do złudzenia przypominajace dwie choragwie i drzewce na rewersie medalu należace do przedstawicieli szlachty. Kolejny baldachim $z$ motywem lilii królewskich zawieszony został na czterech sznurach nad głównym celebransem i następca tronu Francji.

Przystępując do wymienienia cech wspólnych rewersu medalu i ryciny, należy zaznaczyć, że ze względu na różny przebieg i szczegóły koronacji królewskich: Augusta II Wettyna oraz Ludwika XV Burbona medalier, inspirując się opisywaną ryciną portretowa, był zmuszony dokonywać modyfikacji wcześniejszego przedstawienia. Najbardziej zbliżony do medalierskiego odpowiednika wydaje się jednak ołtarz ukazany w lewej części ryciny. W obydwu przypadkach mamy do czynienia ze zbliżonym zestawem przedmiotów na mensie ołtarzowej. O ile jednak na medalu, po prawej i lewej stronie od krucyfiksu znajduja się po dwa świeczniki, o tyle na rycinie, po prawej i lewej stronie od krucyfiksu rytownik upamiętnił po dwie pary świeczników. Na drugiej stronie medalu poza wymienionymi krucyfiksem i dwoma świecznikami, na mensie leży jeszcze 
tylko zamknięta księga do nabożeństwa. Natomiast na rycinie, na mensie ołtarzowej, oprócz wymienionych przedmiotów i zamkniętej księgi liturgicznej prezentowane sa także korona clausa i berło na poduszce. Jednakże najbardziej charakterystyczny element oprawy ołtarza - baldachim został zarówno przez medaliera, jak i rytownika odwzorowany w zbliżony sposób, tzn. $z$ obydwoma połami odsuniętymi na boki i zawiązanymi. Na odwrocie medalu, ze względu na ograniczenia medalowego krążka, medalier wyeksponował w całości jedynie prawa połę baldachimu, którego górna część również pozostaje niewidoczna. Przechodząc do głównych bohaterów kompozycji medalierskiej i graficznej, należy stwierdzić, że jedynie pozycję klęcząca przyjętą przez przyszłego Ludwika XV Burbona (oznaczonego na rycinie litera A) można porównywać do pozycji klęczącej przyszłego Augusta III Wettyna. Ta sama uwaga dotyczy połaczonych ze sobą w geście modlitewnym dłoni koronowanych następców tronu tak na rewersie medalu, jak i na rycinie. Natomiast gesty czynione przez głównego celebransa (oznaczonego na rycinie litera B), namaszczającego swą lewą dłonią skronie władcy francuskiego świętymi olejami i dzierżącego w prawej dłoni tacę (na rycinie), w żadnym razie nie nawiąują do gestów głównego celebransa nakładającego koronę clausa trzymaną oburącz na głowę następcy Augusta II Wettyna (na rewersie medalu). Ciekawym zabiegiem zastosowanym zarówno przez medaliera, jak i rytownika było utrwalenie na drugim planie jednego $z$ biskupów pomocniczych (widoczna jedynie głowa uhonorowana mitra i fragment kapy biskupiej), na rewersie medalu między głównym celebransem a koronowanym, na rycinie zaś między głównym celebransem a jednym $z$ biskupów (oznaczonym litera E). Wśród pozostałych postaci uwzględnionych na rycinie jedynie księcia de Villars (oznaczonego litera P) można próbować porównywać z Ignacym Ancietą Zawiszą na rewersie medalu. Pierwszy jednak ma na sobie albę (?), płaszcz podbity gronostajem, żabot pod szyją, rękawiczki, pończochy i trzewiki oraz łańcuch z Orderem Świętego Ducha narzucony na ramiona. Drugi natomiast odziany jest jedynie w żupan przewiazany pasem kontuszowym i płaszcz kontusz $z$ rozciętymi rękawami. Również miecz obecny na kompozycjach medalierskiej i graficznej przez księcia de Villars jest ściskany jedynie w lewej dłoni. Natomiast Ignacy Ancieta Zawisza prezentuje miecz, posługując się obydwoma dłońmi. Podobna wydaje się również materia obrzeżona frędzlami na posadzce. O ile jednak na rewersie medalu zakrywa 
ona dwa stopnie podestu i starcza zarówno dla koronowanego jak głównego celebransa, o tyle na rycinie jest nałożona na posadzke przed podestem jedynie w miejscu, gdzie klęczy koronowany. Pozostałe postacie i atrybuty na rewersie medalu nie maja swoich odpowiedników na rycinie.

Dolna część ryciny została zaplanowana na legendę: „LE SACRE DE LUIS XV ROY DE FRANCE ET DE NAVARRE a Reims le 25 Octobre 1722. Cette Auguste Cerimonie cefait avec la Ste Ampoule depuis l'an 496 a N. Dame de Reims par. l'Archevque dudlielieu assiste des douxes Ducs Comtes et Paires de France; accompagne des plus illustres Princes Seigneurs et grands Officiers du Royaume avec une magnificence eaetraordinaire.

A. Le Roy.

B. l'Archêveque de Reims M de Rohan Guemene.

C. l'Evêque Duc de Laon M de St Albin.

D. l'Evêque Duc de Langres M de Clermont-Tomnnerre.

E. l'Evêque Comte de Beauvais M de St. Agnan.

F. l'Evêque Comte de Chaolons M de Tavannes.

G. l'Evêque Comte de Noyon M de Roche-bonne.

H. Monseig le Regent represantantle le Duc de Bourgogne.

I. M le Duc de Chartres le Duc de Normandie.

K. M le Duc le Duc de Guyenne.

L. M le Comte de Charolois le Comte le Flandre.

M. M le Prince de Conty le Comte de Toulouse.

N. M le comte de Toulouse, le comte de Champagne.

O. l'Infante Reyne accompagnee des Princesse de la Cour.

P. M le Marechal Duc de Villars representant le Connestable.

Q. M le Garde des Sçeauac representant le Chancelier.

R. l'Abbé de St Remy tenant la Ste Ampoule, S. la Musique du Roy.

T. Seigneurs et Dames assistans a cette celebre Journée.

A Paris Cheu Chiquet rue St. Jacque au Grand St. Henry”.

Zachował się także żeton koronacyjny Ludwika XV Burbona datowany na $1722 \mathrm{r}^{21}$ (il. 3). Rewers wzmiankowanego numizmatu również wykazuje podobieństwo do kompozycji rewersu medalu Augusta II Wettyna. Tym niemniej artysta zaprojektował go zapewne,

${ }^{21}$ Własność prywatna. Przedmiot wystawiony na aukcje antykwariatu „Aureo \& Calicó SL", 18 IX 2014 r., aukcja 262, kat. nr 3077. 

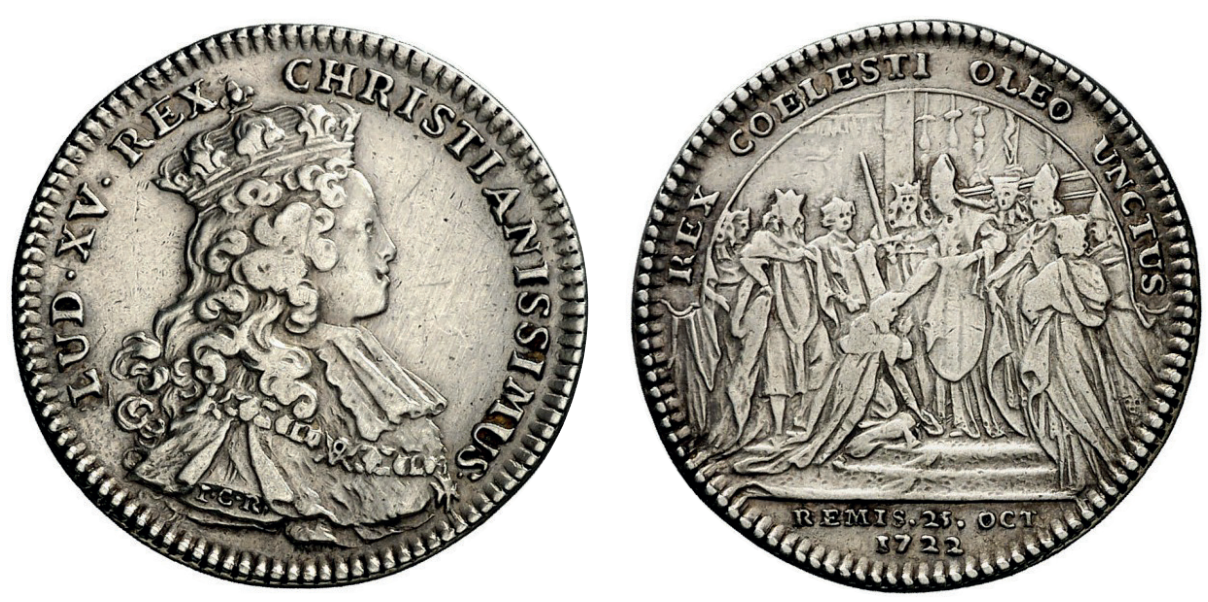

3. Żeton koronacyjny Ludwika XV Burbona, brak sygnatury autora, 1722, śr. 15,5 mm, srebro, bity. Własność prywatna. Przedmiot wystawiony na aukcji antykwariatu „Aureo \& Calicó SL”, 18 IX 2014 r. (aukcja 262, kat. nr 3077)

bazujac na innej rycinie lub rycinach. Akt sakry królewskiej odtworzył medalier w środkowej części. Stojący na stopniach ołtarza arcybiskup $\mathrm{w}$ albie $\mathrm{z}$ długimi rękawami oraz ornacie przy pomocy lewej, wyprostowanej w łokciu, ręki namaszcza świętymi olejami monarchę. W prawym, zgiętym w łokciu, ręku biskupa znajduje się taca. Na prawo od biskupa artysta oddał, w pozycji stojącej, kolejnego biskupa w albie, płaszczu spiętym pod szyją broszą oraz mitrze biskupiej. Między głównym celebransem a opisywanym kolejnym biskupem należne miejsce zajmuje zapewne dostojnik świecki w płaszczu i płaskim nakryciu głowy (mitrze książęcej?). Dwóch kolejnych dostojników oglądający zauważy w prawej części krążka. Pierwszy z nich ma na sobie płaszcz przewiazany pod klatka piersiowa sznurem lub pasem oraz niskie nakrycie głowy (mitrę książęcą?). Drugi natomiast w podobnym płaszczu ma mitrę biskupią. Z kolei postać po lewej stronie głównego celebransa, w płaszczu $z$ korona aperta oraz $z$ mieczem w lewym ręku należy łączyć $z$ księciem de Villars. Następna postać, w płaszczu i niskim nakryciu głowy i z otwartą księga dzierżoną oburącz, to zapewne dostojnik kościelny pomagający w liturgii (na lewo od księcia de Villars). Trzecia w końcu postać, w szacie spodniej i płaszczu spiętym pod szyją oraz koronie aperta z lewą ręką, zgiętą w łokciu i opartą o bok (na lewo od opisywanego dostojnika kościelnego), jak należy przypuszczać, zważywszy na wymienione najważniejsze $z$ insygniów, 
była posiadaczem tytułu książęcego. Za jej plecami artysta umieścił jeszcze trzy kolejne postacie w tym dwie w nakryciach głowy i płaszczach oraz jedna w płaszczu, której poznanie rysów głowy uniemożliwia napis w otoku. W prawej części kompozycji ustawiony jest ołtarz, na którego mensie leżą krucyfiks oraz trzy świece osadzone w świecznikach (na lewo od krucyfiksu). Napisy: otokowy - REX COELESTI OLEO UNCTUS i w odcinku, w dolnej części - REMIS 25 OCT 1722 dotyczą samego aktu sakry królewskiej.

Niewattpliwie istnieje związek między obydwoma kompozycjami medalierskimi. Po pierwsze, główni bohaterzy uroczystości na odwrocie medalu Augusta II Wettyna - biskup Lipski i następca tronu Augusta II Wettyna zostali uchwyceni w identycznych momentach co arcybiskup Remis i następca tronu Ludwika XIV Burbona, tzn. kiedy pierwszy stoi, a drugi klęczy przed nim. Tak samo jak na rycinie, tak również na drugiej stronie medalu Ludwika XV Burbona główny celebrans nie koronuje następcy tronu, a namaszcza go poprzez naniesienie na skronie przyszłego władcy świętych olejów lewą ręka, podczas gdy prawą, zgiętą w łokciu rękę, wykorzystuje do trzymania tacy. Natomiast biskup Lipski na rewersie medalu Augusta III Wettyna, posługując się obydwoma rękami, koronuje przyszłego panującego koroną clausa. Co ciekawe, zbliżony na rewersach medali Augusta III Wettyna i Ludwika XV Burbona wydaje się zwłaszcza dwustopniowy podest zakryty materia, na którym odbywa się właściwy akt koronacji i namszczenia. Szczególnie interesująco przedstawia się prawa część obydwu kompozycji medalierskich. Jak się wydaje, twórcy omawianych dzieł sztuki zrealizowali tam taki sam wzorzec kompozycyjny. $\mathrm{Na}$ prawo od głównego celebransa, zarówno na rewersie medalu Augusta III Wettyna, jak i na drugiej stronie medalu Ludwika XV Burbona, można wyróżnić trzy postacie: pierwszą - pełniącą funkcję kościelne, stojąca za plecami głównego celebransa, a także dwie kolejne postacie: w przypadku rewersu medalu Augusta III Wetyna - dostojników świeckich (na skraju prawej części krążka), w przypadku odwrocia medalu Ludwika XV Burbona - dostojnika świeckiego i dostojnika kościelnego (na skraju prawej części krążka). W przypadku dostojnika kościelnego (pierwszej postaci) można mówić o zbliżonym ubiorze, w postaci alby, płaszcza zapiętego pod szyją oraz mitry biskupiej, uwypuklonym na obydwu krążkach medalierskich. $Z$ kolei w przypadku dwóch dostojników świeckich stroje sa odmienne. Na rewersie medalu Augusta III Wetyna maja 
oni kontusze $z$ rozciętymi na całej długości rękawami i żupany $z$ długimi rękawami. Natomiast na drugiej stronie medalu Ludwika XV Burbona ubrani sa w długie płaszcze spięte pod klatka piersiową sznurami. Jedynie ich nakrycia głowy (mitra książęca? i mitra biskupia) uświadamiały odbiorcę o ich obowiązkach i prerogatywach. $Z$ kolei wśród grupy postaci zgromadzonych na lewo od głównego celebransa jedynie podobizna księcia de Villars ze względu na główny atrybut w postaci miecza może być traktowana jako daleka podstawa dla wizerunku Ignacego Anciety Zawiszy. Tak$\dot{z}$ e tu stroje wymienionych bohaterów reprezentują zupełnie inne trendy w modzie. Ubiór Ignacego Anciety Zawiszy - płaszcz kontusz $z$ rozciętymi na całej długości rękawami, żupan $z$ długimi rękawami i pas kontuszowy - to typowe przykłady mody sarmackiej. $Z$ kolei strój i atrybuty księcia de Villars - płaszcz gronostajowy i korona aperta - stanowiły odzwierciedlenie posiadanego przezeń tytułu książęcego. W końcu na rewersie medalu Ludwika XV Burbona tak samo jak na rycinie miecz zlokalizowany jest w lewym ręku księcia. $Z$ kolei na rewersie medalu Augusta III Wettyna do prezentowania miecza Ignacy Ancieta Zawisza angażuje obydwie ręce. Mimo zbliżonych przedmiotów spoczywających na mensie ołtarzowej: krucyfiksu ze świecami w świecznikach po obu jego stronach (na rewersie medalu Augusta III Wettyna) bardzo trudno jest doszukiwać się analogii $z$ wystrojem mensy ołtarzowej z krucyfiksem i trzema świecami w świecznikach po jego lewej stronie (na rewersie medalu Ludwika XV Burbona).

Podsumowując, należy stwierdzić, że twórca medalu koronacyjnego Augusta III Wettyna (Heinrich Paul Groskurt), projektując w 1734 r. rewers medalu, wykorzystał wykonaną wcześniej rycinę Du sacre des rois de France, rytowana przez Felixa Lacointa Mercure'a w $1722 \mathrm{r}$. W mniejszym stopniu pomoc dla medaliera stanowił rewers, datowanego na 1722 r., żetonu koronacyjnego Ludwika XV Burbona. Wzmiankowane dzieła sztuki, które należy zakwalifikować jako wzorce inspiracji dla medaliera, sa proweniencji francuskiej. Świadczy to niezbicie o tym, że dysponent akceptował fakt, że medalier podczas pracy inspirował się wzorcami znad Sekwany. Zważywszy, że faworytem króla arcychrześcijańskiego (Ludwika XV) był bowiem Stanisław Leszczyński, pozostaje więc zadać sobie pytanie o cele, jakimi kierował się nowy polski władca, godząc się na utrwalanie własnego aktu sakry królewskiej w nawiązaniu do podobnych uroczystości odbywających się we Francji. 
Należy jednak podkreślić, że o ile twórcy francuscy (rytownik i medalier) zdecydowali się uwzględnić na kompozycji swych prac jedynie moment namaszczenia skroni władcy świętymi olejami, będacy chronologicznie pierwszym, o tyle medalier działający dla Wettynów utrwalił na drugiej stronie medalu z 1734 r. scenę nałożenia na głowę władcy korony clausa, następująca już po namaszczeniu świętymi olejami. Warto w tym miejscu zadać pytanie o motywy artysty. Jak się wydaje, Groskurt mógł chcieć nawiązać do symboliki najważniejszego $z$ insygniów koronacyjnych korony clausa - doskonale obrazujaccej znana od średniowiecza zasadę ustrojowa "Rex imperator in regno suo”. August III Wettyn, mimo że objął koronę po swym ojcu, zawsze pozostawał jedynie monarchą elekcyjnym, którego wyniesienie na tron bez zgody szlachty byłoby niemożliwe. Stąd też być może wynikała potrzeba podkreślenia własnych prerogatyw, zwłaszcza w kontekście samego aktu koronacji, który przecież niewiele odbiegał od podobnych uroczystości organizowanych na innych dworach europejskich.

Jednocześnie analizując rewers medalu, należy zwrócić uwagę na dwie inskrypcje: w otoku: CONCORDIBUS LIBERAE GENTIS SUFFRGIIS (Zgodnymi wolnego narodu głosami) oraz w odcinku w dolnej części: ELECT[us] V OCT[obris] MDCCXXXIII. CORONATIS XVI JAN[uarii] MDCCXXXIV (Obrany 5 października 1733 r.) stanowiące komentarz do opisywanej sceny koronacji Wettyna. Tak wyraźne stwierdzenie przez autora inskrypcji, że o godności królewskiej Wettyna zadecydowały głosy „wolnego narodu” szlacheckiego oddane podczas elekcji 5 października 1733 r., staje się całkowicie zrozumiałe w kontekście rzeczywistych wydarzeń historycznych i zwycięstwa elekcyjnego Stanisława Leszczyńskiego 12 września $1733 \mathrm{r}$. 


\section{Bibliografia}

\section{Ź RÓDEA DRUKOWANE}

Albertrandy J., Album rycin medali i monet $z$ płyt przygotowanych do dzieła x. Biskupa Jana Albertrandego w latach 1822-1828 znajdujacych się obecnie $w$ Akademii Sztuk $w$ Petersburgu, [b.m. i r.w.] (Muzeum Narodowe w Poznaniu, Gabinet Numizmatyczny, księgozbiór podręczny, nr inw. 7465a).

Albertrandy J., Historya polska ostatnich trzech wieków medalami zaświadczona i objaśniona, rękopism około $200 \mathrm{w}$ polskim języku skreślony, a częścia $i$ po francuzku napisany, znajdował sie $w$ bibliotece $b$. Warszawskiego Towarzystwa Przyjaciół Nauk, [b.m. i r.w.] (Biblioteka Raczyńskich w Poznaniu, sygn. Rkp 4).

Bentkowski F., Spis medalów polskich lub z dziejami krainy polskiej stycznych, $w$ gabinecie Król. Alex. Uniwersytetu $w$ Warszawie znajdujacych się, tudzież ze zbiorów i pism rozmaitych lub podań zebrany i porzadkiem lat ułożony, Warszawa 1830.

Dyaryusz Prawdziwy wjazdu do stołecznego Krakowa i koronacyi tamże, Fryderyka Augusta Elektora Sasuego [...], [w:] Dwie Koronacye Sasów Augusta II i Augusta III ze współczesnego rękopisu ogłosił [...] W. Syrokomla, przeł. W. Syrokomla, Wilno 1854, s. 21-28.

Hauschild J.F., Beytrag zur neuern Münz und Medaillen Geschichte vom XVten Jahrhundert bis jetzo, nebst einem raisonnirenden Verzeichniß einer beträchtlichen Sammlung von Medaillen in allen Classen und von allem Metall, auch einiger 100 Stück seltner Thaler, mit Anmerkungen von Johann Friedrich Hauschild, Dresden 1805.

Raczyński E., Gabinet Medalów Polskich oraz tych które się dziejów Polski tycza poczawszy od wstapienia na tron Augusta II aż do zgonu syna jego Augusta III (1697-1763), t. III, Wrocław 1838.

\section{Opracowania}

Ciesielski T., Armia koronna w czasach Augusta III, Warszawa 2009.

Ciesielski T., Propagandowy wymiar uroczystości dworskich $w$ pierwszych latach panowania Augusta III, „Wieki Stare i Nowe” 2015, nr 8(13), s. 46-68.

Dygdała J., Konfederacja krakowska Teodora Lubomirskiego z początków bezkrólewia 1733 roku a polityka Austrii wobec Rzeczypospolitej, [w:] Trudne stulecia. Studia $z$ dziejów XVII i XVIII wieku ofiarowane Profesorowi Jerzemu Michalskiemu $w$ siedemdziesiata rocznice urodzin, red. Ł. Kądziela, W. Kriegseisen, Z. Zielińska, Warszawa 1994, s. 46-54.

Dygdała J., Urażone magnackie ambicje czy racja stanu? U źródeł opozycji wobec kandydatury Stanisława Leszczyńskiego w bezkrólewiu 1733 roku, [w:] Spory o państwo $w$ dobie nowożytnej. Między racja stanu a partykularyzmem, red. Z. Anusik, Łódź 2007, s. 187-199.

Dygdała J., Wizerunek barokowego sarmaty i oświeceniowego Europejczyka, czyli August III Wettyn i Stanisław August Poniatowski, „Wieki Stare i Nowe” 2014, nr 6(11), s. 38-57. 
Europa $i$ świat $w$ epoce oświeconego absolutyzmu, red. J. Staszewski, Warszawa 1991.

Forrer L., Biographical dictionary of medallists-coin, gem, and seal-engravers, mint-masters, \&c., ancient and modern, vol. I-VIII, London 1904-1916.

Hutten-Czapski E., Catalogue de la collection des médailles et monnaies polonaises du comte E. Hutten-Czapski, t. I-V, St. Petersbourg-Cracovie 1871-1916.

Hutten-Czapski E., Spis rycin przedstawiajacych portrety przeważnie polskich osobistości w zbiorze Emeryka hrabiego Hutten-Czapskiego w Krakowie, Kraków 1901.

Łomnicka-Żakowska E., Graficzne portrety Augusta II i Augusta III Wettynów w zbiorach Muzeum Narodowego w Warszawie, Warszawa 1997.

Łomnicka-Żakowska E., Grafika portretowa epoki saskiej $w$ Polsce $w$ relacji z późnobarokowa grafika europejska, Warszawa 1997.

Medale Polskie i z Polska zwiazane z okresu pierwszej Rzeczypospolitej. Katalog zbiorów-zamek królewski w Warszawie-muzeum. Fundacja zbiorów im. Ciechanowieckich, red. J. Zachert, G. Śnieżko, M. Zawadzki, Warszawa 2019.

Pod jedna korona. Kultura i sztuka w czasach unii polsko-saskiej. Zamek Królewski w Warszawie - 26 czerwca - 12 października 1997 roku, red. M. Męclewska, B. Grątkowska-Ratyńska, Warszawa 1997.

Staszewski J., August II, Warszawa 1985.

Staszewski J., August III, Warszawa 1984.

Staszewski J., August III Sas, Wrocław 1989.

Staszewski J., O miejsce w Europie. Stosunki Polski i Saksonii z Francją na przełomie XVII i XVIII wieku, Warszawa 1973.

Staszewski J., Polacy w osiemnastowiecznym Dreźnie, Wrocław 1987.

Zbiory Poznańskiego Towarzystwa Przyjaciół Nauk w Muzeum Narodowym w Poznaniu. Katalog wystawy, red. Z. Białłowicz-Krygierowa, M. Warkoczewska, Poznań 1982.

NOTKA O AUTORZE:

Dr Jan Gustaw Rokita - historyk, absolwent Wydziału Nauk Historycznych i Społecznych Uniwersytetu Kardynała Stefana Wyszyńskiego w Warszawie, przewodniczący Rady Miejskiej Góry Kalwarii VIII kadencji (2018-2023). Autor licznych artykułów dotyczacych medalierstwa czasów Jana III Sobieskiego, opublikowanych m.in. w „Zeszytach Naukowych Uniwersytetu Jagiellońskiego”, „Studiach Historycznych”, „Biuletynie Numizmatycznym” i innych wysoko punktowanych periodykach: „Seminare”, „Res Historica”, „Studia Europaea Gnesnensia”.

Zainteresowania naukowe: medalierstwo i malarstwo czasów nowożytnych.

( janrokita1@gmail.com 